\title{
Visualisation Method of Electromyogram in Rehabilitation and Training of Patients with Cerebral Palsy
}

\author{
Katrina Caikovska ${ }^{1}$, Juris Lauznis ${ }^{2}$ \\ ${ }^{1,2}$ Riga Technical University
}

\begin{abstract}
The aim of the study is to develop visualisations suitable for rehabilitation and training of patients with cerebral palsy in home conditions. The specially prepared visualisations were demonstrated to 10 children with cerebral palsy to find the most effective visualisations based on their own opinion. During the experimental part of this study, electromyogram, vital signs and skin conductance measurements of volunteer participants were registered. After the experimental part, participants and physiotherapists were interviewed.

It was concluded that a biofeedback method of electromyography is suitable as a rehabilitation method in home conditions, if the visualisation is based on multimedia.
\end{abstract}

Keywords-Biofeedback, cerebral palsy, children electromyogram, rehabilitation.

\section{INTRODUCTION}

A cerebral palsy is damage to the parts of the brain that control the motor function of the body. This damage results in a group of permanent movement disorders, which are common in children [1].

Rehabilitation of patients with cerebral palsy is a long and expensive process, which in most cases includes long-term hospitalisation [2].

Previous studies suggest that using a biofeedback training method in rehabilitation of cerebral palsy can improve the motor function of patients [3], [4].

Biofeedback method of electromyography is a simple, lowcost method that together with a simple and comprehensible visualisation could be performed in home conditions [5].

For implementation of biofeedback in these conditions, it is necessary to develop the visualisation of electromyogram suitable for children with cerebral palsy rehabilitation and training. The goal of the present research is to prepare different versions of electromyogram visualisations and determine the best version based on a patient feedback.

\section{VisUALISATIONS AND THE WORKING PRINCIPLES}

10 different visualisations were developed using MindMedia software Biotrace+. Firstly, electromyogram signal has to be converted to an amplitude envelope. Secondly, inthe graph of the electromyogram the threshold level for muscle biopotential must be set [6].

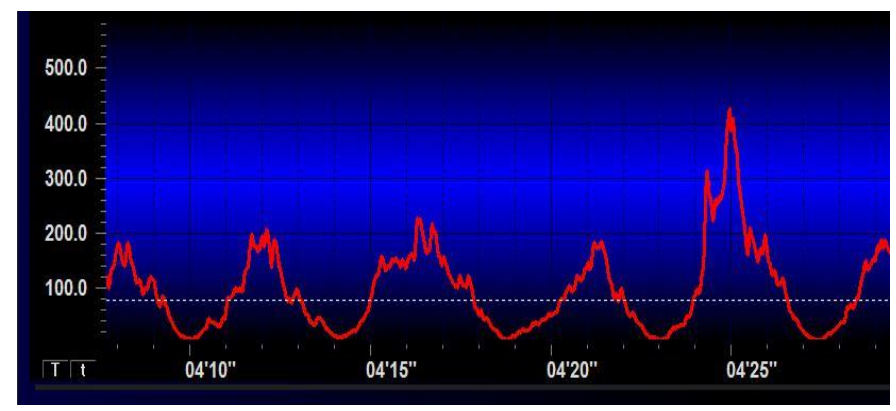

Fig. 1. Electromyogram converted to an amplitude envelope. The horizontal line is threshold.

The level of threshold is selected and adjusted by the physiotherapist during the biofeedback training. If the electromyogram reaches the level of threshold or is above it, the software activates the visualisation - plays a video, for example. If the level falls back under the level of threshold, the video is stopped.

The following images display the interfaces of the visualisations.

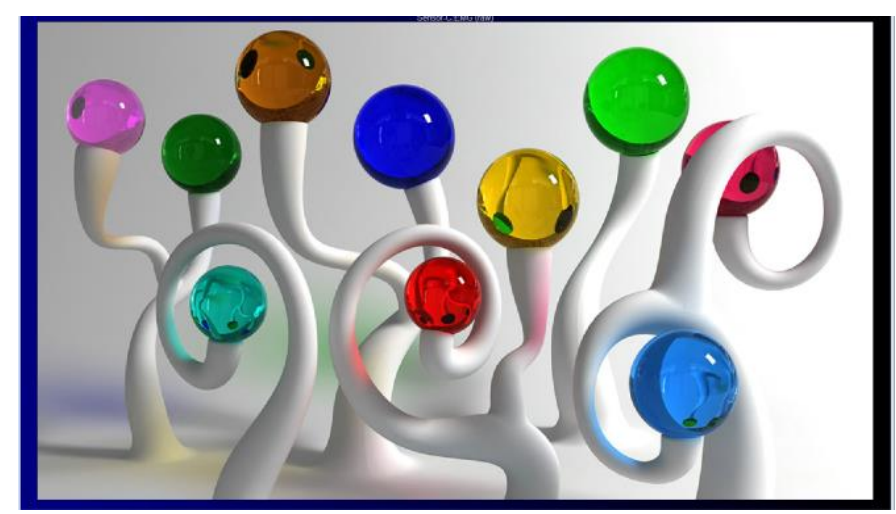

Fig. 2. Visualisation "glowing lamps" - when a muscle biopotential reaches the selected level of threshold, the lamps light in different colours consecutively. If the muscle biopotential level falls back, the lights of the lamp disappear. 


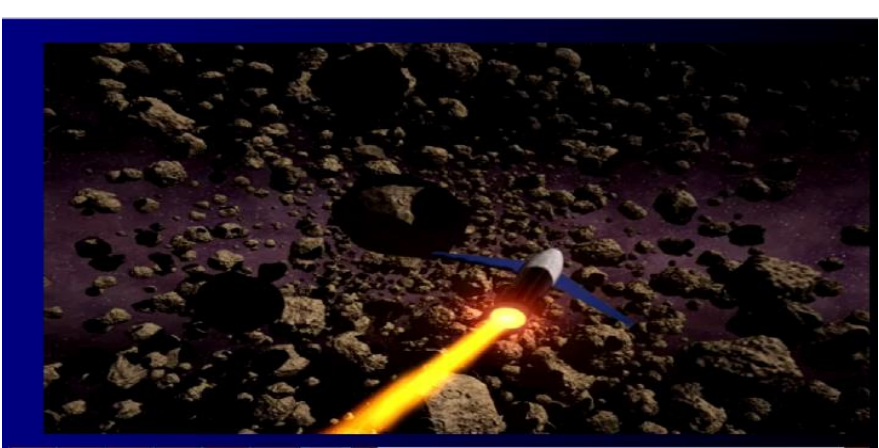

Fig. 3. Visualisation "video" (flying rocket in space) - when the muscle biopotential is above the selected level, video is in play mode. When it falls back, the video is in pause mode.

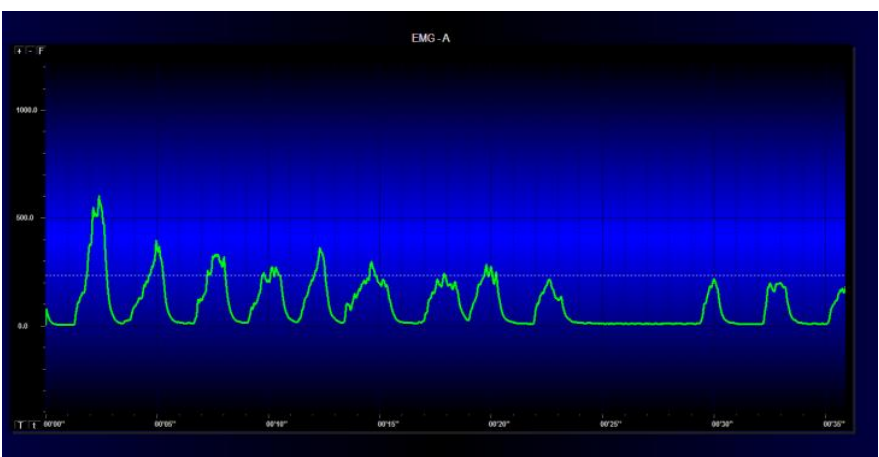

Fig. 4. Visualisation "electromyogram Ampl" (electromyogram converted to an amplitude envelope) displays the muscle biopotential in real time.

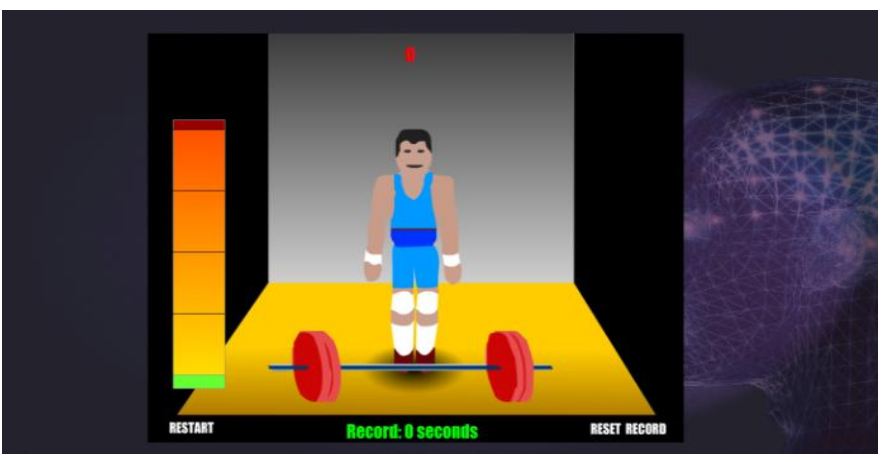

Fig. 5. Visualization "game" - when the muscle biopotential is above the threshold, athlete lifts weights and the timer is started. If the biopotential decreases under the threshold, athlete lowers the weights and the timer is stopped.

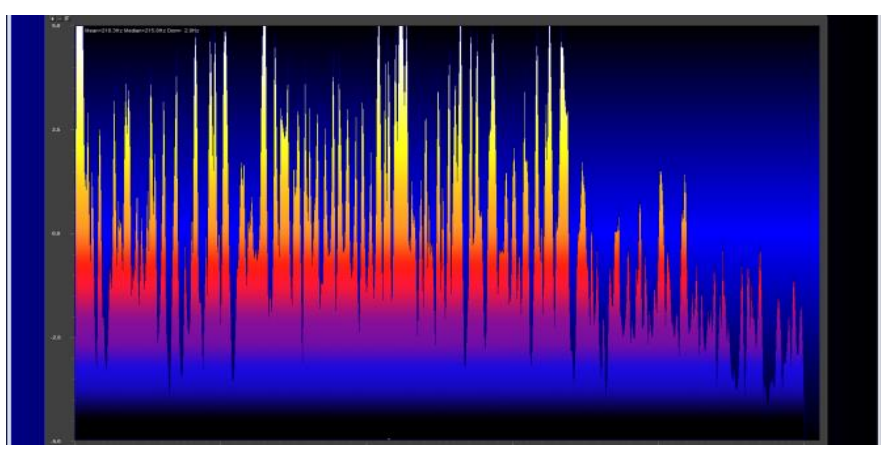

Fig. 6. Visualisation "spectral analysis" - the relocation of EMG -the signal by the frequency is displayed.

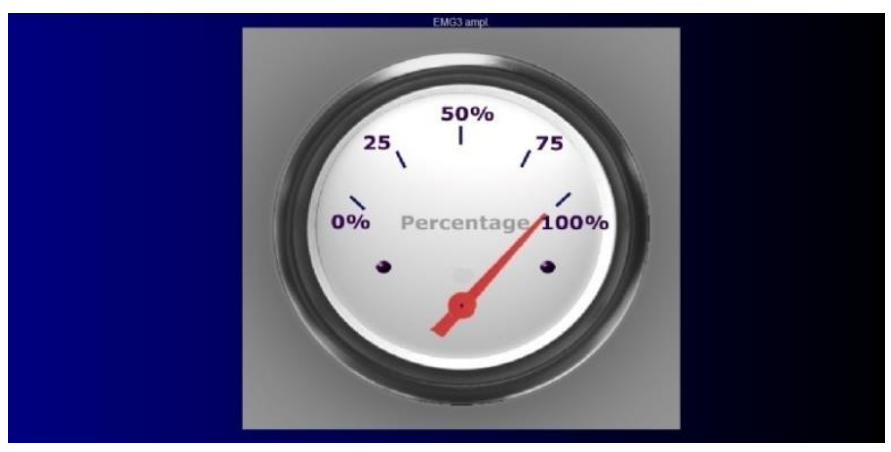

Fig. 7. Visualisation "speedometer" - when the muscle biopotential is above the selected level, speedometer reading increases. If the muscle biopotential decreases under the threshold, the reading decreases.

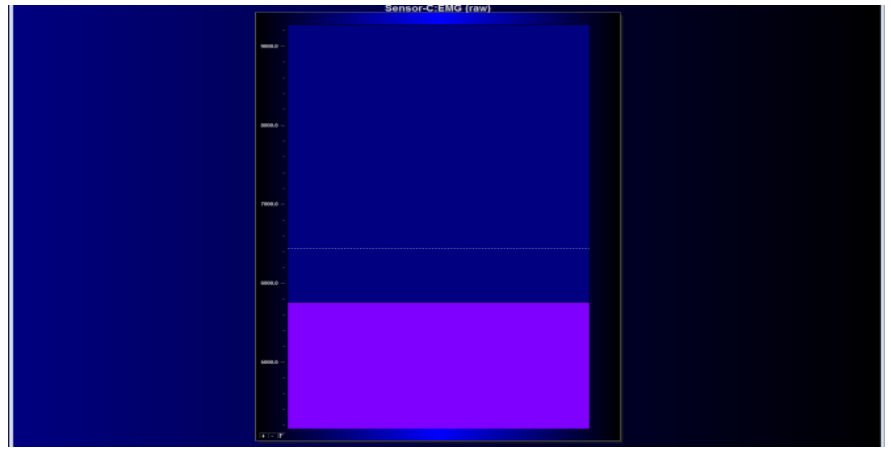

Fig. 8. Visualisation "level indicator" - the visualisation indicates the amplitude of electromyogram "Envelope", likewise Fig.4.

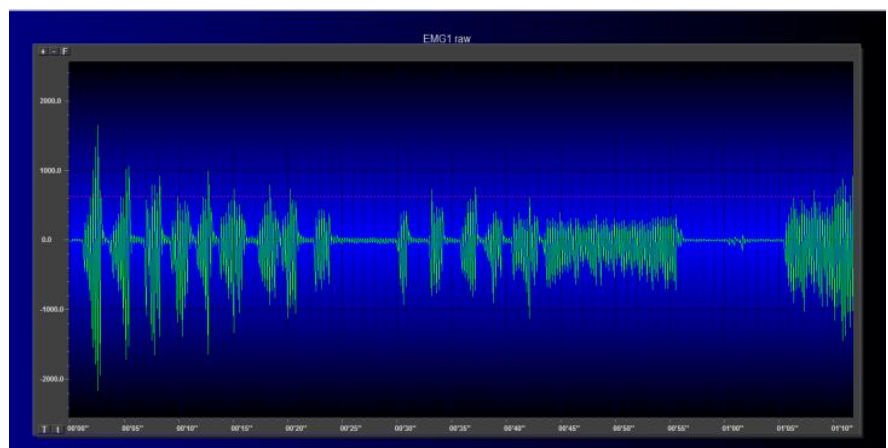

Fig. 9. Visualisation "electromyogram as is" - displays the muscle biopotential curve in real time.

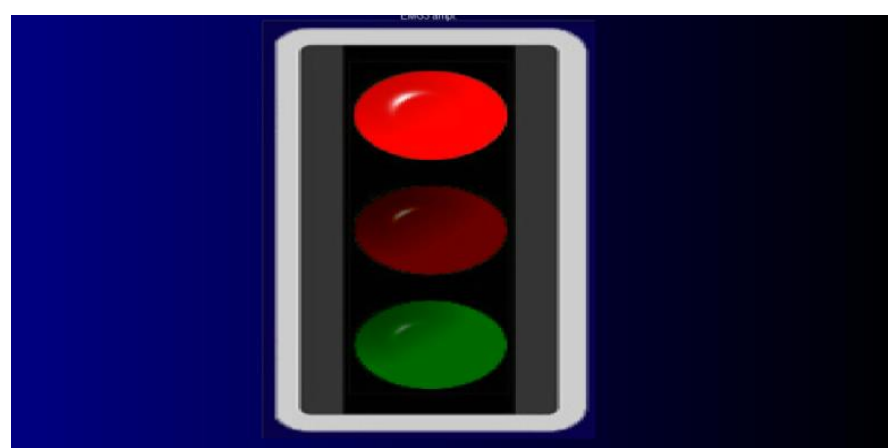

Fig. 10. Visualisation "traffic light" - when the muscle biopotential is above the threshold, red light is displayed. If the biopotential reaches the threshold level, yellow light is displayed. If the biopotential is above the threshold, green light is displayed. 


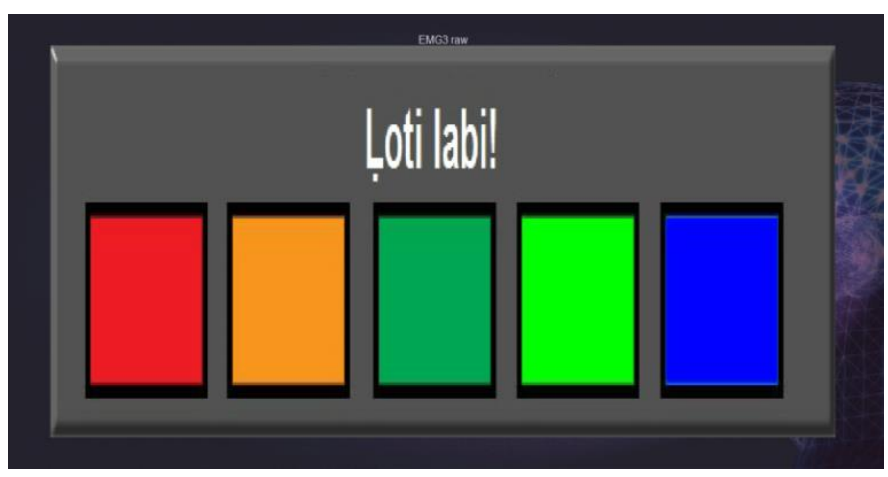

Fig. 11. Visualisation "power level" - If the muscle biopotential is below the threshold, there are no colours displayed. When the biopotential reaches the threshold level, the red colour is displayed. If the muscle biopotential is held above the threshold, orange, green and blue colours are displayed consecutively.

All visualisations can be reversed - the feedback can be implemented if the muscle biopotential is under the threshold, for example, visualisation "video" is in "play" mode, if the biopotential is under the threshold level and "pause" mode, if the biopotential is above it. This way a relaxation exercise could be performed.

\section{TECHNOLOGY OF MEASUREMENTS}

Patient vitals were registered using MindMedia device NeXus-10 MKII, which includes 8-channel electromyography. This device also registers vital measurements of patients respiration rate, pulse and skin conductivity.

There are two monitors used during the biofeedback training of participants. Participant's monitor displays only one of the visualisations at a time. Physiotherapist monitor displays electromyogram and participant's vital measurements.

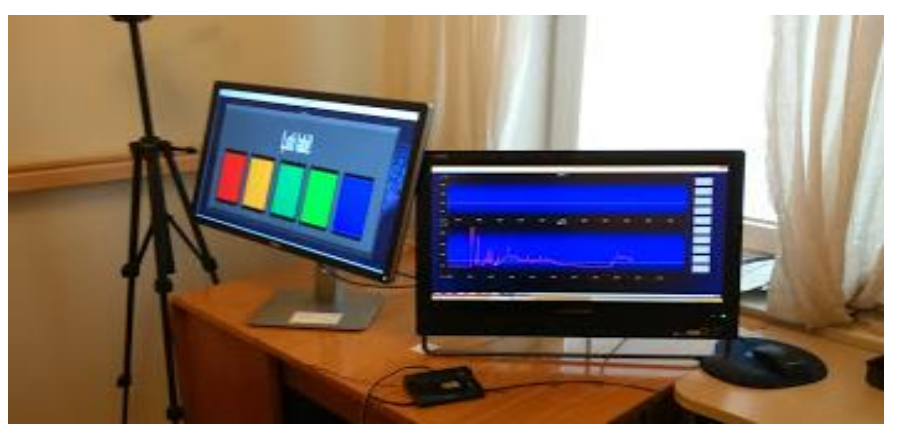

Fig. 12. Monitors used in biofeedback - monitor on the left side is participant's monitor.

Patient vitals were measured using pulse oximeter placed on participant's index finger, respiration sensor/belt placed around chest (between breasts and belly button) and skin conductivity sensors placed on participant's middle and ring fingers. Vitals were registered by obtaining a curve of measurements before visualisations were demonstrated, during the demonstrations and after the demonstrations. The software allowed putting automatic markers in curves when the visualisations were changed.
The pulse was calculated by counting the maximum amplitudes of pulse curve during the visualisation and divided by the interval of time. The pulse cure is shown in Fig. 13.

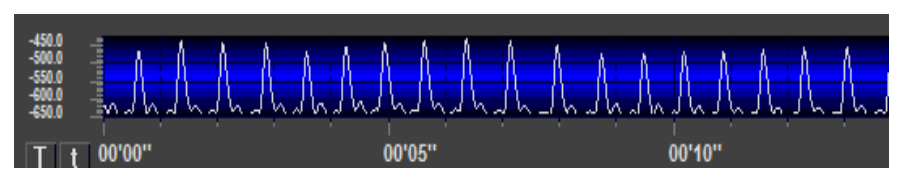

Fig. 13. The curve of participant's pulse.

The calculation formula of pulse is shown in (1). $P$ is the calculated pulse, $P^{\prime}$ is the counted maximum amplitudes of the pulse curve in the time interval, $t$ is the time interval.

$$
P=P^{\prime} \cdot \frac{60}{t},
$$

Similar method was used to calculate a respiration rate. The obtained respiration curve is shown in Fig. 14.

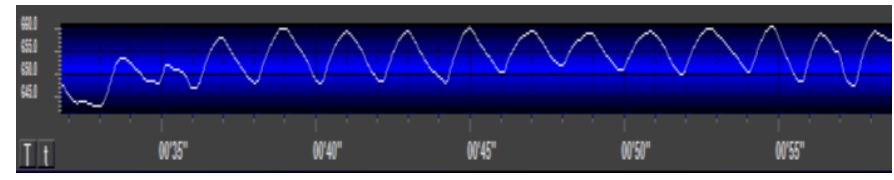

Fig. 14. The curve of participant's respiration.

The calculation formula of respiration rate is shown in (2). $R$ is the calculated respiration rate, $R^{\prime}$ is the counted maximum amplitudes of the respiration curve in the time interval, $t$ is the time interval.

$$
R=R^{\prime} \cdot \frac{60}{t}
$$

Measurements were made by comparing vital readings of the current visualisation in relation to the previous one.

Skin conductivity measurements were taken by analysing their graphical chart and by rehabilitation and training observations. The example of the skin conductivity curve is shown in Fig. 15.

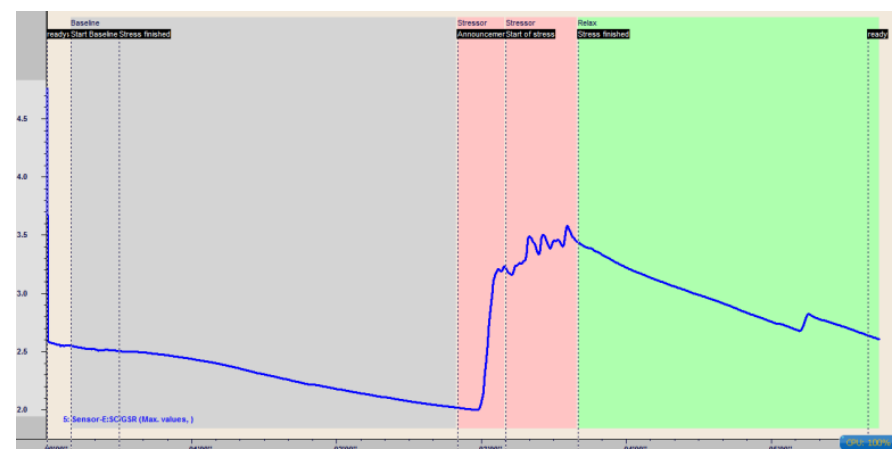

Fig. 15. The curve of participant's skin conductivity.

To determine the visualisation which is the most suitable for a certain participant, we look at their vitals during the test. If the vitals go down, the visualisation is deemed fit for that participant. In other words, the less worried the participant is, the better a particular visualisation is for him or her. The most appropriate visualisation (least stressful) is one that lowers or at least does not increase skin conductivity. A minor or steady 
$2015 / 16$

increase in conductivity is considered normal during a physical exercise.

\section{PARTICIPANTS}

10 anonymous participants took part in this research $(5$ men and 5 women), aged 13-24. All participants are diagnosed with cerebral palsy. None of the participants have mental disabilities.

Cerebral palsy has affected the participants differently there are cases of hemiplegia, diplegia and tetraplegia. Each participant's body parts were affected differently; therefore, the type of exercise was chosen individually for each participant. The exercises were chosen by the physiotherapists and it was the most difficult exercise for each of the patients individually at that time. 3 participants during electromyogram performed a hand rotation exercise, 3 performed a foot lifting exercise and the remaining 4 performed a weight transferring exercise in the hips.

\section{METHOD}

To determine the most suitable visualisation, the research included three criteria:

1. Registration of vitals - pulse, respiration rate and skin conductivity,

2. Questionnaire of patients,

3. Questionnaire of physiotherapists.

Before the biofeedback training, parents of the participants were interviewed to determine whether the participants had an understanding of the visual media environment (computer, mobile phone etc.). 7 of 10 participants work with computer daily and 3 participants - a few times a week. It was concluded that all participants understood videos, games and animations equally well.

At the beginning of the biofeedback training, a visualisation screening was performed. All ten visualisations were demonstrated to the participants. Each participant selected the three most attractive and comprehensible visualisations in his or her opinion, after which the biofeedback training was performed. Every participant had three sessions with the selected three visualisations. All three visualisations were demonstrated in each session. Working with the visualisations required some adaptation; therefore, it was necessary to avoid the last visualisation having the best results. This was done by choosing a random order in which the visualisations were demonstrated.

Sessions were controlled and performed by certified physiotherapists, 4 in total. During a session, a training protocol was filled with the participant's vital measurements, observations of training and questionnaire. Physiotherapists filled their questionnaire after the last session.

\section{RESULTS AND DISCUSSION}

After the results of visualisation screening, the most often selected visualisations were "traffic light" and "spectral analysis" - these visualisations were selected by 5 out of 10 participants. According to the participants, the visualisation "traffic light" attracted attention because it was familiar and easy to understand, while "spectral analysis" attracted attention because the visualisation was very colourful. There was no correlation between the age of the participants and screening results of visualisations "traffic light" and "spectral analysis".

In the screening, none of the participants selected "level indicator". The visualisation "glowing lamps" was selected by 3 women and 0men, the visualisation "speedometer" was selected by 3 men and 0 women. Therefore, we believe that these visualisations cause interest in certain gender.

The results of visualisation screening are shown in Fig. 16.

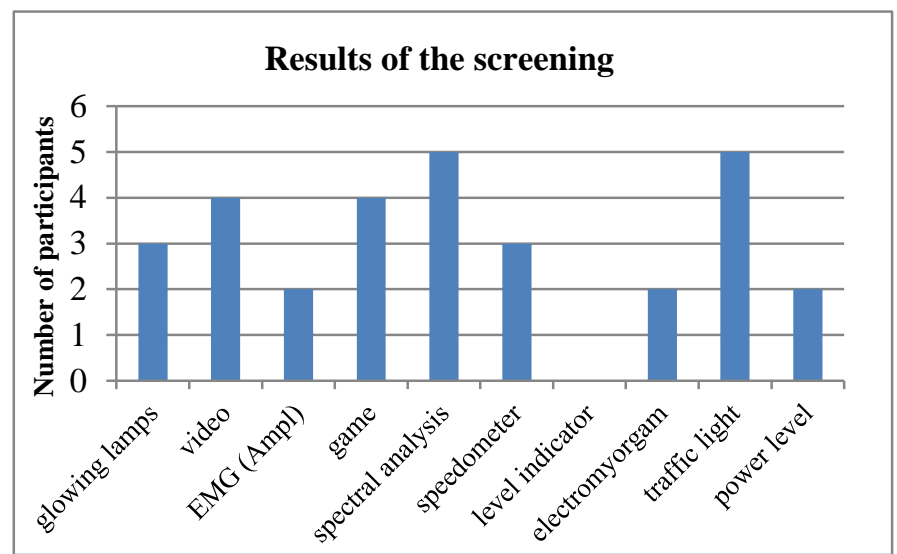

Fig.16. The results of the visualisation screening.

If we divide participants into two groups by age, the first group is $13-18$ and the second is $19-24$. The visualisations with electromyograms were selected by 1 participant in the first group and 3 participants in the second group. In turn, the visualisation "game" was selected by 3 participants in the first group and 1 participant in the second group. Therefore, we believe that these visualisations cause interest at a certain age.

Participants were asked in the questionnaire which visualisation was the easiest and which the hardest to understand and perform. The most successful visualisation, according to the results, was "traffic light". None of the participants suggested "speedometer" as the less successful visualisation.

The results of patients' questionnaire are shown in Figs. 17 and 18 .

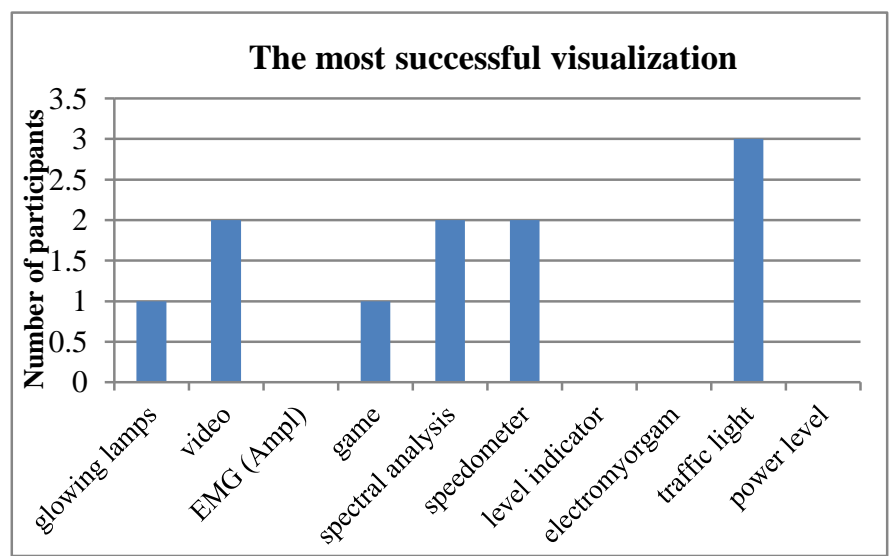

Fig.17. The results of participants' questionnaire - the most successful visualisation. 


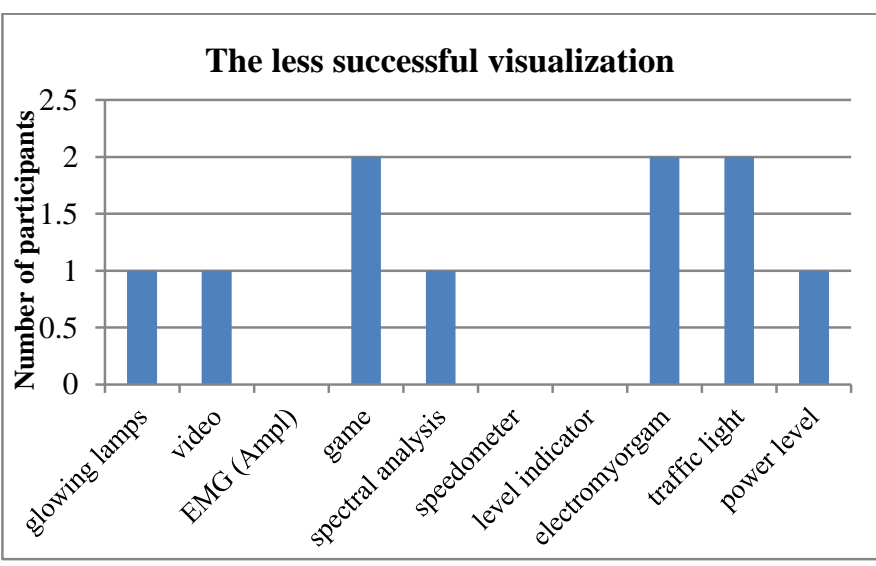

Fig. 18. The results of participants' questionnaire - the less successful visualisation.

Visualisations "traffic light" and "spectral analysis" had the highest result according to the vital measurements of the participants. "Traffic light" and "spectral analysis" were determined as the most suitable visualisations by 3 participants, while "game" caused additional stress to 3 participants.

After the biofeedback training, the physiotherapists were interviewed. 2 out of 4 physiotherapists considered visualisations "traffic light" and "speedometer" to be universal visualisations suitable for all types of exercises during the biofeedback training. One physiotherapist suggested "power level" as the most successful visualisation. Physiotherapists viewed "glowing lamps" as a suitable exercise for muscle strength and "game" as an unsuitable exercise for muscle relaxing. In physiotherapists' opinion "video" could not be used as a weight transferring exercise.

To compare the multimedia based visualisations with visualisations of electromyogram, the screening was performed repeatedly after the last session of biofeedback training. None of the participants chose visualisations of electromyogram or electromyogram converted to an amplitude envelope. It may be concluded that visualisations of electromyogram do not cause further interest in participants.

\section{CONCLUSION}

1. Biofeedback method of electromyography is a suitable rehabilitation method in home conditions, if the visualisation is based on multimedia.

2. Visualisation "traffic light" is considered to be the most suitable visualisation for rehabilitation and training in home conditions because it attracts attention, causes interest, is easy to understand and it is suitable for different types of exercises for improving muscle activity and relaxation.
3. Visualisation "game" caused additional stress to participants.

4. Future vision is to adapt the visualisations for rehabilitation of cerebral stroke patients.

\section{ACKNOWLEDGEMENT}

The present research has been conducted and supported by the Union "For Latvian Children with Disabilities" and by physiotherapists Egija, Anita, Liva and Elita.

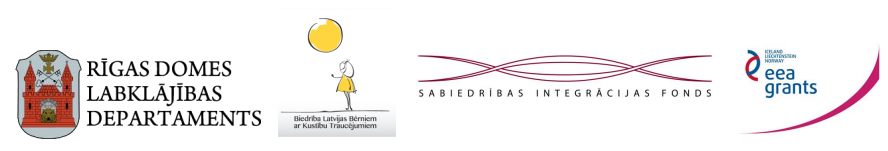

\section{REFERENCES}

[1] Dodd K.J., Imms C., Taylor N.F., Physiotherapy and occupational therapy for people with cerebral palsy. London: Mac Keith press, 2010. p. 305.

[2] Doğan-Aslan M., Nakipoğlu-Yüzer G.F., Doğan A., etc."The Effect of Electromyographic Biofeedback Treatment in Improving Upper Extremity Functioning of Patients with Hemiplegic Stroke, "J. of Stroke and Cerebrovascular Diseases, vol. 21, Issue 3, April 2012, pp.187192.http://dx.doi.org/10.1016/j.jstrokecerebrovasdis.2010.06.006

[3] Dursun E., Dursun N., Alican D., "Effects of biofeedback treatment on gait in children with cerebral palsy,"Disabil Rehabil, vol.26, 2004,pp. 116-120.http://dx.doi.org/10.1080/09638280310001629679

[4] Bloom R., Przekop A., Sanger T.D. „Prolonged electromyogram biofeedback improves upper extremity function in children with cerebral palsy," J. Child Neurol, vol. 25, 2010. http://dx.doi.org/10.1177/0883073810369704

[5] Giggins O.M., McCarthy U. and Caulfield B., "Biofeedback in rehabilitation," J. of Neuro Engineering and Rehabilitation, 2013, p. 11. http://dx.doi.org/10.1186/1743-0003-10-60

[6] Mind Media Bio Trace software manual. 2014

Katrina Caikovska graduated the Master's programme "Medical Physics and Engineering" at Riga Technical University in 2015. Research interests include: medical devices, medical information systems, biomechanics, radiation protection and quality control assessment in medical imaging.

She is currently working as a Medical Physicist at Riga East Clinical

University Hospital.

Address: 6k, Ezermalas Str., Riga, LV-1006, Latvia.

E-mail: katrina.caikovska@gmail.com

Juris Lauznis is an Elected Researcher (2009) at Riga Technical University, the Faculty of Computer Science and Information Technology, the Institute of Computer Control, Automation and Computer Engineering. He has 22 scientific publications and 3 patents (in the last 10 years). Research interests include: medical information systems and electronic devices, microprocessor control, embedded systems, data acquisition systems, wireless communications.

He is a member of the Board of the Latvian Association of Medical Device Manufacturers and Service Providers and a member of the Board of the Latvian Society of Medical and Biological Engineering.

Address: 2, Daugavgrivas Str., Riga, LV-1007, Latvia.

E-mail: Juris.Lauznis@rtu.lv

Katrīna Čaikovska, Juris Lauznis. Elektromiogrammas vizualizācijas metode cerebrālās triekas pacientu rehabilitācijai un treniṇiem

Rakstā aprakstīts pētījums par bioatgriezeniskās saites elektromiogrāfijas metodes piemērotību bērnu cerebrālās triekas rehabilitācijas nodarbībām mājas apstāklıs.

Pētījuma mērḳis ir izveidot elektromiogrāfijas vizualizācijas metodi, kas būtu piemērota bērnu cerebrālās triekas pacientu rehabilitācijai un treniṇiem mājas apstākḷlos. Pētījumā tika sagatavoti vizualizāciju varianti, un tie tika demonstrēti 10 brīvprātīgajiem bērnu cerebrālās triekas pacientiem, lai noteiktu efektīvāko vizualizāciju pēc pacientu uztveres. Eksperimentālās dalas laikā pacientiem tika reǵistrēta elektromiogramma, vitālie mērījumi un ādas vadītspēja. Pēc eksperimentālās daḷas tika veikta pacientu un fizioterapeitu aptauja. Pētījuma eksperimentālā daḷa tika izstrādāta, izmantojot ražotāja MindMedia iekārtu "Nexus-10". Pētījuma rezultātā tika izstrādātas rekomendācijas reǵistrācijas iekārtas izveidei.

Elektromiogrāfijas bioatgriezeniskās saites metode ir piemērota kā rehabilitācijas metode mājas apstākḷos, ja tās vizualizācija ir veidota multividē. 
$2015 / 16$

Катрина Чайковска, Юрис Лаузнис. Метод визуализации электромиограмм для реабилитации больных церебральным параличом

В научной статье описывается исследование возможности использования биологической обратной связи по обработанному сигналу электромиографии и применение ее для реабилитации пациентов с детским церебральным параличом в домашних условиях.

Цель исследования-разработать метод электромиографической визуализации, который можно будет применить для реабилитации, в том числе при тренировках, в случае церебрального паралича у пациента-ребёнка. Для того, чтобы определить наиболее эффективный метод визуализации, было разработано множество вариантов, клинический эффект которых тестировался на 10 -ти детях-добровольцах. В ходе эксперимента регистрировалась электромиограмма, основные жизненные показатели, а также проводимость кожи. После экспериментальной части проводился анализ результатов на основе опросов пациентов и квалифицированных специалистов (врачей-физиотерапевтов). Экспериментальная часть исследования проводилась с использованием аппарата Nexus-10 (программа Biotrace+) компании MindMedia.

В ходе исследования были разработаны рекомендации для разработки упрощённого регистрационного прибора ЕМГ и программы визуализации. Разработанный метод биологической обратной связи по обработанному сигналу электромиографии применим в качестве метода реабилитации в домашних условиях, при условии, что метод визуализации был разработан в мультимедийной среде. 